\title{
B-type natriuretic peptide levels and diagnostic accuracy: excess fluid volume
}

How to cite this article: Trojahn MM, Barilli SLS, Bernardes DS, Pedraza LL, Aliti GB, Rabelo-Silva ER. B-type natriuretic peptide levels and diagnostic accuracy: excess fluid volume. Rev Gaúcha Enferm. 2020;41(esp):e20190095. doi: https://doi.org/10.1590/19831447.2020.20190095 a Instituto de Cardiologia da Fundação Universitária de Cardiologia (IC-FUC), Porto Alegre, Rio Grande do Sul, Brasil.

Hospital Nossa Senhora da Conceição (HNSC). Porto Alegre, Rio Grande do Sul, Brasil.

Pontifícia Universidade Católica do Rio Grande do Sul (PUCRS), Hospital São Lucas. Porto Alegre, Rio Grande do Sul, Brasil.

¿ Universidade Federal do Rio Grande do Sul (UFRGS), Programa de Pós-Graduação em Ciências da Saúde: Cardiologia e Ciências Cardiovasculares. Porto Alegre, Rio Grande do Sul, Brasil.

e Universidade Federal do Rio Grande do Sul (UFRGS) Escola de Enfermagem. Porto Alegre, Rio Grande do Sul, Brasil.

\section{Melina Maria Trojahna \\ Sofia Louise Santin Barillib \\ Daniela de Souza Bernardesc \\ Letícia Lopez Pedraza $^{d}$ \\ Graziella Badin Aliti ${ }^{\mathrm{e}}$ \\ Eneida Rejane Rabelo-Silva ${ }^{\mathrm{e}}$}

\section{ABSTRACT}

Aim: To analyze the behavior of B-type natriuretic peptide (BNP) in the presence of defining characteristics (DCs) of the nursing diagnosis Excess fluid volume (00026) in patients hospitalized for acute decompensated heart failure.

Methods: Cohort study of patients admitted with acute decompensated heart failure (September 2015 to September 2016) defined by Boston Criteria. Patients hospitalized for up to $36 \mathrm{~h}$ with BNP values $\geq 100 \mathrm{pg} / \mathrm{ml}$ were included; BNP values at baseline-final assessment were compared by Wilcoxon test, the number of DCs at baseline-final assessment was compared by paired $t$-test.

Results: Sixty-four patients were included; there was a significant positive correlation between delta of BNP and the number of DCs present at initial clinical assessment.

Conclusions: The behavior of BNP was correlated to the DCs indicating congestion. With clinical compensation, DCs and BNP decreased. The use of this biomarker may provide additional precision to the nursing assessment.

Keywords: Heart failure. Nursing diagnosis. Biomarkers. Nursing. Cardiology. Signs and symptoms.

\section{RESUMO}

Objetivo: Analisar o comportamento do peptídeo natriurético tipo B (BNP) na presença de características definidoras (CDs) do diagnóstico de enfermagem Excesso de volume de líquidos (00026) em pacientes hospitalizados por insuficiência cardíaca descompensada.

Métodos: Estudo de coorte com pacientes internados com insuficiência cardíaca descompensada (setembro-2015 a setembro-2016), definida pelos Critérios de Boston. Pacientes hospitalizados por mais de 36 horas, valor de BNP $\geq 100 \mathrm{pg} / \mathrm{ml}$ foram incluídos; valores de BNP basal-final foram comparados pelo teste Wilcoxon; as CDs no basal-final foram comparadas pelo teste t pareado.

Resultados: Sessenta e quatro pacientes foram incluídos; houve correlação positiva significativa entre o delta de BNP com o número de CDs presentes na avaliação clínica inicial.

Conclusões: 0 comportamento do BNP foi correlacionado com as CDs, indicando congestão. Com a compensação clínica, as CDs e a concentração de BNP diminuíram. 0 uso deste biomarcador pode fornecer precisão adicional à avaliação de enfermagem.

Palavras-chave: Insuficiência cardíaca. Diagnóstico de enfermagem. Biomarcadores. Enfermagem. Cardiologia. Sinais e sintomas.

\section{RESUMEN}

Objetivo: Analizar el comportamiento del péptido natriurético tipo B (BNP) en presencia de características definitorias (CD) del diagnóstico de enfermería Exceso de volumen de líquidos (00026) en pacientes hospitalizados por insuficiencia cardíaca aguda descompensada (ICAD).

Métodos: Estudio de cohorte de pacientes ingresados con ICAD (septiembre/2015 a septiembre/2016).Se incluyeron pacientes hospitalizados hasta $36 \mathrm{~h}$ con valores de BNP $\geq 100 \mathrm{pg} / \mathrm{ml}$; Los valores de BNP en la evaluación inicial basal se compararon mediante la prueba de Wilcoxon, el número de CD en la evaluación inicial basal se comparó mediante el Test-T apareado.

Resultados: Se incluyeron 64 pacientes; hubo una correlación positiva significativa entre el delta del BNP y las CD presentes en la evaluación clínica inicial.

Conclusiones: El comportamiento del BNP se correlacionó con las CD que indican congestión. Con compensación clínica, las CD y el BNP disminuyeron. El uso del BNP puede proporcionar precisión adicional a la evaluación de enfermería.

Palabras clave: Insuficiencia cardíaca. Diagnóstico de enfermería. Biomarcadores Enfermería. Cardiología. Signos y síntomas. 


\section{口INTRODUCTION}

In Brazil, acute decompensated heart failure (ADHF) accounts for a substantial portion of hospital admissions ${ }^{(1)}$ Heart failure (HF) itself is one of the leading causes of morbidity and mortality worldwide, affecting 26 million people in the last five years ${ }^{(2-3)}, 15$ million in Europe alone ${ }^{(3-4)}$.

Clinical congestion, composed of dyspnea, edema, hepatojugular reflux, and jugular venous distension, is the most common manifestation in patients admitted to emergency services for $\mathrm{ADHF}^{(5-6)}$. Studies conducted at emergency departments and HF clinics, where patients often present with these signs and symptoms, indicate that the nursing diagnosis (ND) "Excess fluid volume" is often established ${ }^{(7-8)}$. These findings were validated in a study of patients with decompensated $\mathrm{HF}$ in an emergency setting, indicating that these clinical manifestations are indeed present in the clinical examination performed by nurses ${ }^{(5)}$. Although the ND "Excess fluid volume" (EFV) is accurate for congested patients, it has been suggested by nurses that these signs and symptoms can also reflect conditions of the respiratory system, thus compromising diagnostic accuracy ${ }^{(7)}$.

Recently, a report on the state of the art of early treatment of ADHF demonstrated that medical team decisions upon arrival at the emergency department have a direct impact on morbidity and mortality. The authors showed that $80 \%$ of patients with ADHF presented with defining characteristics of congestion, including presence of third heart sound, dyspnea, orthopnea, positive hepatojugular reflex, jugular vein distension, edema, and paroxysmal nocturnal dyspnea. In this study, the importance of biomarkers - especially B-type natriuretic peptide (BNP) and $\mathrm{N}$-terminal pro-brain natriuretic peptide (NT-proBNP) - was emphasized because they helped improve diagnostic accuracy and speed ${ }^{(6)}$.

Given the importance of establishing a precise diagnosis so that nursing interventions are effective and good patient outcomes are achieved, the possibility of incorporating into the nursing process tools that could corroborate diagnostic accuracy at the bedside must be considered. An accurate diagnosis reflects the patient's real state because it is found through the knowledge and history of the patient, allowing the nurse to plan strategies that have a better prediction capacity for a given diagnosis ${ }^{(11)}$ In the specific case of EFV, one biomarker in particular has been widely studied in the last two decades: BNP, which can be used to distinguish cardiac dyspnea from pulmonary dyspnea $a^{(5,9-10)}$.

To improve the accuracy of diagnosis, ND should be based not only on patients' clinical parameters, but also on laboratory and imaging findings $s^{(11-12)}$. In this perspective, we understand that the use of biomarkers, such as BNP, can corroborate diagnostic accuracy in the clinical assessment of patients with congestive $\mathrm{HF}^{(3,13)}$.

Within this context, this study was designed to analyze the behavior of B-type natriuretic peptide in the presence of defining characteristics of the nursing diagnosis Excess fluid volume (00026) in patients hospitalized for acute decompensated heart failure. Our hypothesis was that BNP level might be added as a new defining characteristics (DC) to this ND.

\section{METHODS}

This was a cohort study with prospective data collection, developed in a master dissertation entitled Behavior of the B-type natriuretic peptide marker and its relation to the nursing diagnosis Excess Fluid Volume in patients hospitalized for decompensated heart failure. These patients were included in an emergency department and inpatient units of a public, university-affiliated hospital in Southern Brazil. The data collection period lasted approximately 12 months (from September 2015 to September 2016).

Inclusion criteria were adult patients with systolic HF or HF with preserved ejection fraction (HFpEF) with a diagnosis of ADHF who met the Boston Criteria with a score of 8 or higher ${ }^{(14)}$. These criteria include patient history, physical examination findings, crackles, and chest $X$-ray findings. Each category carries a maximum score of 4 points (item score of the highest category value). The diagnosis of ADHF can be classified as "definitive" (8 to 12 points), "likely" (5 to 7 points), or "unlikely" (4 points or less) ${ }^{(14)}$.

Besides the Boston criteria, patients hospitalized for up to $36 \mathrm{~h}$ with BNP values $\geq 100 \mathrm{pg} / \mathrm{ml}$ were included; those with infectious conditions, obesity and impaired renal function were excluded due to potential impact of these factors on BNP levels.

After daily screening, the team, which was composed of HF nurses and nursing students trained for this stage, invited patients to participate in the study. Those who agreed and signed an informed consent form were assessed for eligibility by the Boston Criteria ${ }^{(14)}$. After clinical assessment, a 3-ml sample of blood was collected for BNP measurement. Clinical assessment and blood collection occurred within 36 $\mathrm{h}$ of hospital admission and were repeated at final patient assessment (at discharge or 7 days after study inclusion, whichever came first). Clinical data - New York Heart Association (NYHA) classification ${ }^{(15)}$, HF etiology, comorbidities, left ventricular ejection fraction, and current medications - and sociodemographic characteristics were also collected by a researcher, nurse specialist in cardiology. Additional data were obtained from patients' medical records when unavailable at the time of interview. 
The sample size, estimated on the basis of a 0.4 correlation between BNP levels and the number of DCs present at clinical assessment, with a 5\% significance level and 80\% statistical power, was calculated as 47 patients at least.

Pursuant to a previous clinical validation study conducted by nurse specialists in cardiology to test for the presence of the primary defining characteristics (dyspnea, orthopnea, edema, positive hepatojugular reflex, paroxysmal nocturnal dyspnea, pulmonary congestion, and increase in central venous pressure) and secondary defining characteristics (weight gain, hepatomegaly, jugular vein distension, crackles, oliguria, low hemoglobin count, and anemia) of ND Excess fluid volum ${ }^{(5)}$. These are described below as listed in the NANDA-International (NANDA-I) classification ${ }^{(11)}$, as well as their definitions and the new DCs validated and included in the 2015-2017 edition of NANDA-I: hepatomegaly and paroxysmal nocturnal dyspnea ${ }^{(5,11)}$.

BNP values were obtained from laboratory records after each patient's final assessment. The reference range for BNP is $<100 \mathrm{pg} / \mathrm{ml}$ for patients not diagnosed with ADHF and $>400-500 \mathrm{pg} / \mathrm{ml}$ for patients with confirmed $\operatorname{ADHF}^{(3,12)}$. BNP levels were checked by the team at the end of patient follow-up to avoid a selection bias.

Statistical analyses were carried out in SPSS version 20.0. The Shapiro-Wilk test was used to test for normality of data distribution. Continuous variables were expressed as mean and standard deviation or median and interquartile range as appropriate. Categorical variables were expressed as absolute and relative frequencies. Spearman's rank correlation coefficients were used to calculate the relationship between the number of primary and secondary DCs of Excess fluid volume and the delta-BNP (variation of BNP's values). BNP values at baseline and at final assessment were compared using the Wilcoxon signed-rank test, while the number of DCs present at baseline vs. at final assessment was compared through a paired $t$-test. A $p$ - value $<0.05$ was considered statistically significant.

The study was approved by the institutional Research Ethics Committee under number 150.362 (CAAE: 47661315200005327).

\section{Q RESULTS}

We evaluated 64 adults. The patients were predominantly elderly (age $69 \pm 13$ years) and male ( $n=34,53 \%)$. Mean LVEF was $50 \pm 16 \%$. The most common HF etiologies were hypertension (39\%) and ischemic heart disease (36\%). Patient weight declined during the hospitalization period (78 $\pm 20 \mathrm{~kg}$ at admission vs. $75 \pm 20$ at final assessment), as did the Boston score (10 [8-11] at admission vs. 5.5 [4-7] at final assessment). The median length of stay was 7 (4-17) days, and hypertension was the most prevalent comorbidity (81\%).

There was a moderate and significant positive correlation between delta-BNP* and the number of DCs of Excess fluid volume present at baseline clinical assessment $(r=0.304$, $p=0.018$ ). Figure 1 .

Median BNP* values reduced significantly from baseline to final assessment (381 [202-707] pg/ml vs. 309 [180-640] $\mathrm{pg} / \mathrm{ml}$ respectively, $\mathrm{p}=0.012$ ).Figure 2 .

The figure 3 shows the frequencies of the primary and secondary DCs of the nursing diagnosis Excess fluid volume at baseline and at final patient assessment. The decline in frequency observed for most DCs is consistent with improvement of congestion over the course of hospitalization.

In a quantitative analysis of the DCs of Excess fluid volume, a reduction in the number of DCs present over the course of hospitalization was also observed, from $11 \pm 3$ at admission to $7.5 \pm 3$ at final assessment $(p<0.001)$.Figure 3 .

\section{口DISCUSSION}

This was the first study conducted in a real-world clinical setting to analyze the behavior of BNP levels in peripheral blood and their relationship with the nursing diagnosis Excess fluid volume in patients with ADHF. Our findings demonstrate that, during the course of hospitalization and treatment for $A D H F$, as well as a reduction in the number of DCs that indicate systemic venous congestion, this biomarker - indicative of high pressures - also decreased in peripheral blood as the patients became less congested. The correlation between the delta-BNP and the number of DCs of Excess fluid volume present at initial clinical assessment was positive, moderate, and significant. Similarly, quantitative evaluation of DC and BNP showed a significant reduction from baseline to final assessment.

The DCs of the diagnosis Excess fluid volume have been clinically validated in patients admitted for ADHF, i.e., the same population studied in this study ${ }^{(5)}$. Evidence has shown that these DCs are actually indicative of systemic venous congestion, and that their presence denotes heavily decompensated HF due to congestive conditions ${ }^{(3,6)}$.

High BNP values also made the ND Excess fluid volume more accurate in this sample and can confirm the diagnosis of Clinical improvement, indicated by the reduction in BNP values from baseline to final assessment, indicates the importance of clinical evaluation by nurses. Initial assessment of patients with $\mathrm{ADHF}$ in the emergency department plays a decisive role in treatment ${ }^{(13,16)}$. Several studies have noted the importance of combining bedside clinical assessment with BNP measurements $s^{(9,13)}$. 


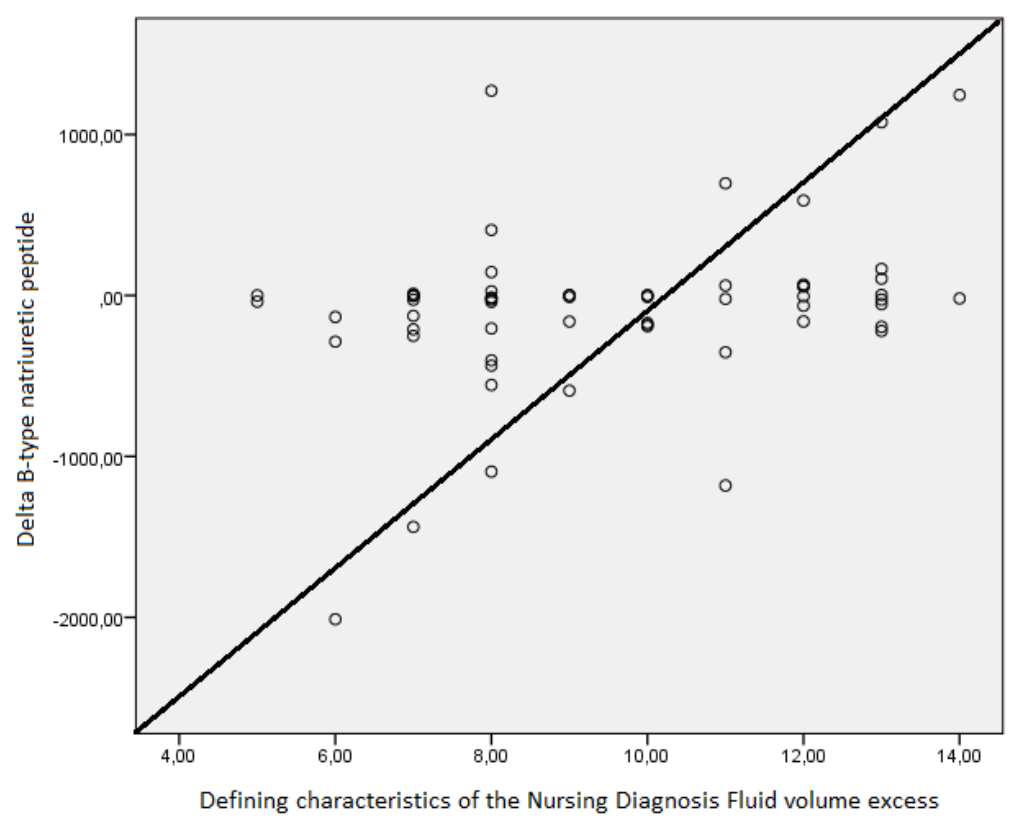

Figure 1 - Correlation between delta-BNP and the 15 defining characteristics of the nursing diagnosis Excess fluid volume (00026) at admission and at final patient assessment.

Source: Research data, 2017

Spearman's rank correlation, $p=0.018$.

* B-type natriuretic peptid

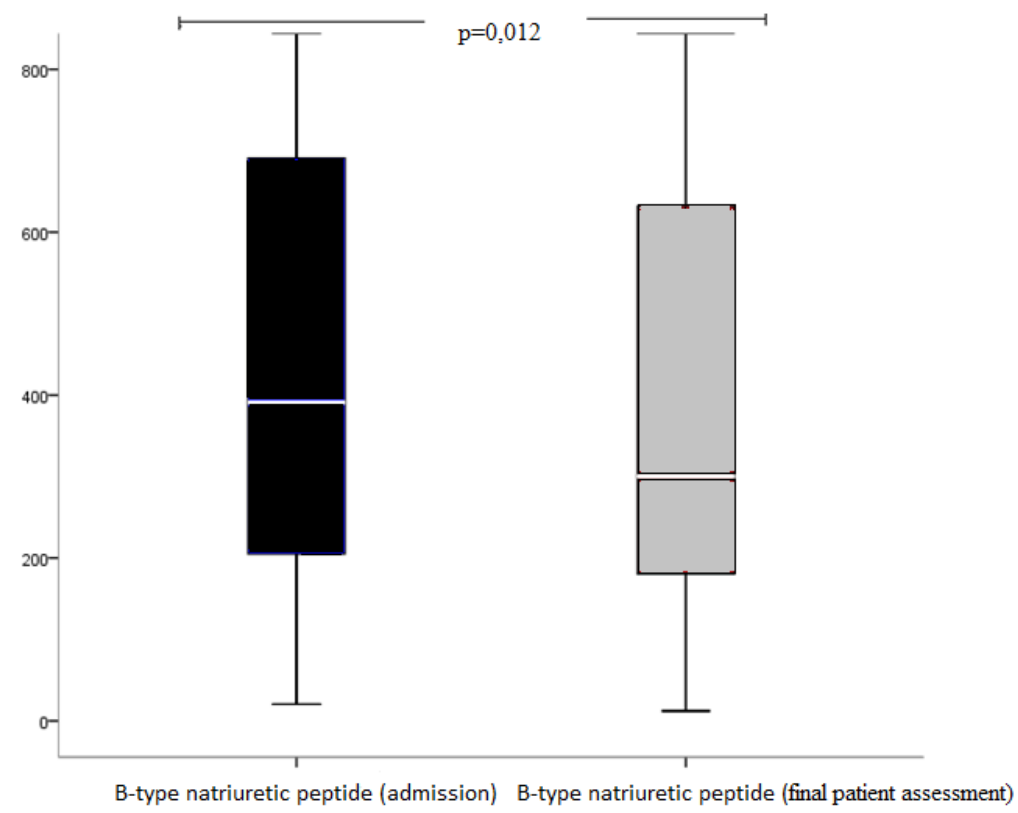

Figure 2 - Median BNP* values at admission and final assessment

Source: Research data, 2017

${ }^{*}$ B-type natriuretic peptide, + Wilcoxon's test, $p=0.012$.

The results of the present study confirm that nurses can use non-clinical parameters to improve their diagnostic accuracy in patients with HF. Such improvement of diagnostic accuracy allows optimization of nursing interventions, especially in emergency-room settings ${ }^{(3,9-10,17)}$.
A previous study confirmed the importance of clinical assessment performed by nurses, even outside the emergency setting. Clinical assessment of patients with HF performed by specialist nurses was compared to evaluation by cardiologists, and the correlation of both assessments with BNP 
a)
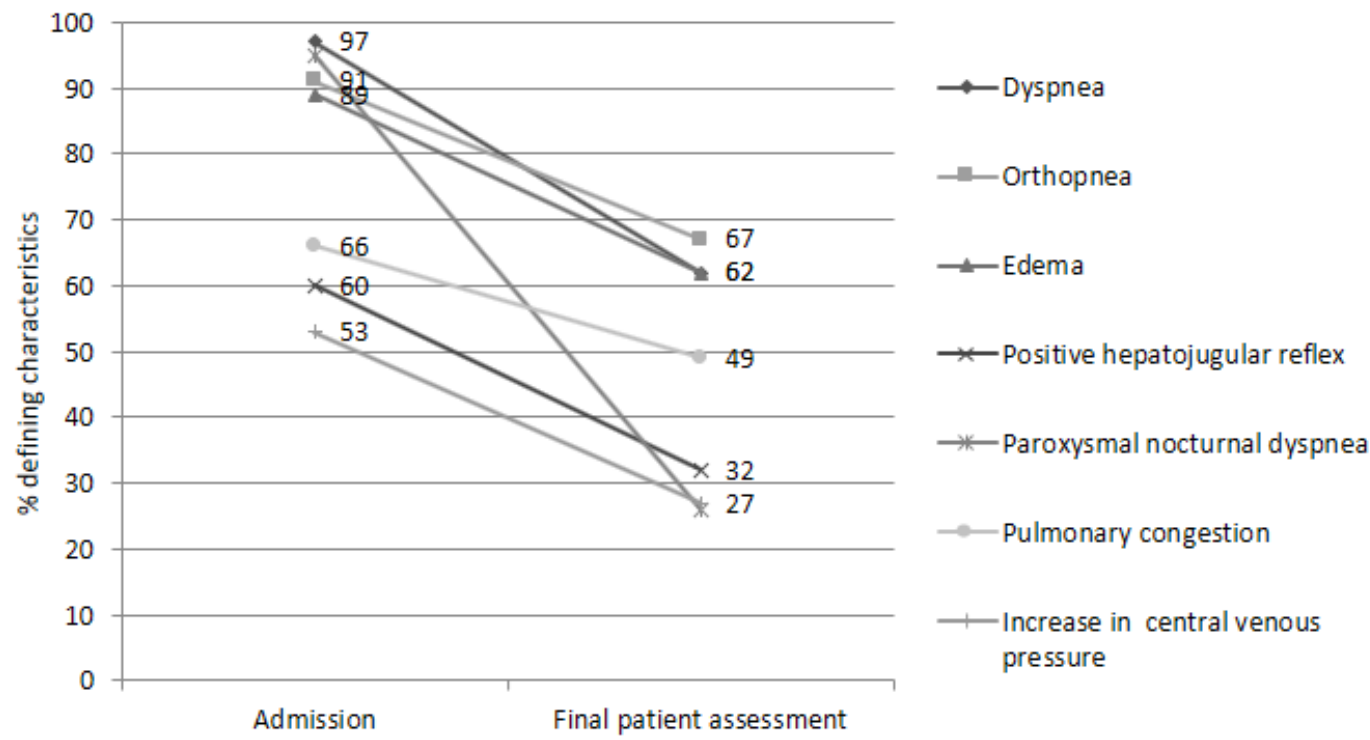

b)
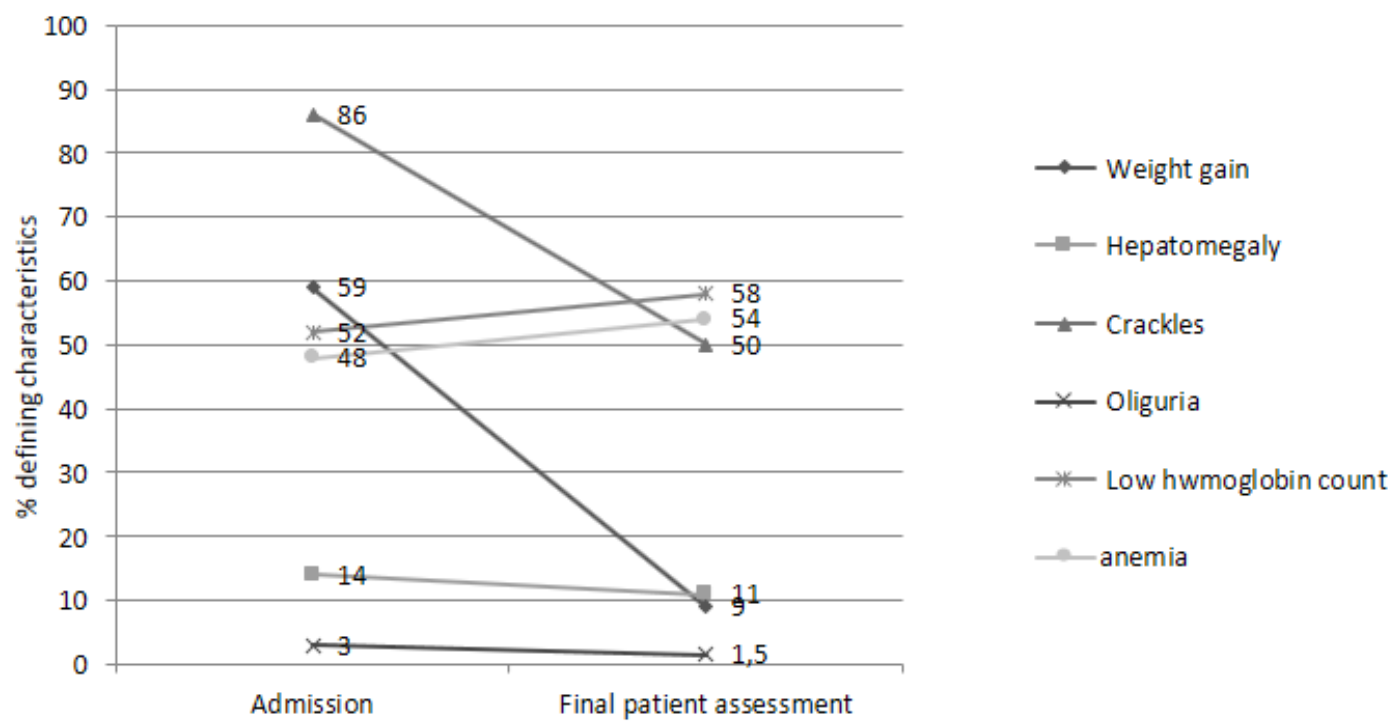

Figure 3 - Relative frequency of patients with (a) primary and (b) secondary defining characteristics of the nursing diagnosis Excess fluid volume at admission and at final patient assessment.

Source: Research data, 2017.

levels was analyzed. The authors found that the congestion assessments performed by nurses were similar to those performed by cardiologists, and that both correlated highly with BNP values ${ }^{(8)}$. In the present investigation, we found a moderate, significant correlation between presence of DCs and BNP values, suggesting that congestion of cardiac etiology was indeed present in patients assigned the ND Excess fluid volume.

The behavior of BNP levels in relation to the presence of DCs of Excess fluid volume (i.e., clinical markers of congestion) has also been confirmed by previous studies, as has the decrease in BNP at discharge in patients who achieve clinical compensation. In a database study of 113 patients with ADHF who achieved compensation (defined as improvement to NYHA class I or II) during hospitalization, BNP levels decreased from $917 \mathrm{pg} / \mathrm{ml}$ at admission to $351 \mathrm{pg} / \mathrm{ml}$ after treatment. The authors concluded that BNP levels not only reflect the severity of HF and the likelihood of cardiovascular events, but also are representative of better clinical condition ${ }^{(16)}$. Besides the reduction of BNP values which is observed after clinical compensation of congestion, the values measured at discharge have also been a concern of researchers in clinical practice ${ }^{(16)}$.In a study conducted in Italy, BNP values decreased from admission to discharge, and the authors concluded 
that BNP was an independent predictor for 6-month allcause mortality ${ }^{(18)}$. In addition to the usefulness of BNP for physical examination and degree of congestion of patients, this is also useful for completing the patient's prognosis. In this sense, the nurse has an important role in planning the care plan. Thus, in addition to using this biomarker, nurses can use other key clinical covariates, including worse NYHA, presence of rales and wider QRS duration ${ }^{(10,16)}$.

In the present study, sensitivity and specificity analyses were also performed among the diagnoses established by staff nurses and baseline BNP values. Sensitivity testing revealed that a many nurses established a correct diagnosis when the BNP cutoff value is $413 \mathrm{pg} / \mathrm{ml}$. This indicates that patients with BNP values between 400 and $500 \mathrm{pg} / \mathrm{ml}$ are indeed presenting with $\mathrm{ADHF}$, and that non-cardiac causes of congestion can be ruled out ${ }^{(19)}$.

Clinical decision-making involves many factors, including experience, understanding scientific evidence, and the patient's profile. The use of BNP for diagnosis, treatment and prognosis is already being included in national and international guidelines ${ }^{(1,3)}$.

The findings of the present study regarding BNP behavior and the state of congestion, as indicated by the DCs of Excess fluid volume, show that nurses should consider this biomarker in the different clinical practice scenarios of patients with ADHF. The identification of signs and symptoms of decompensation is essential for decision-making, and clinical examination is paramount. Nevertheless, clinical practice nurses should be familiar with other parameters that may improve diagnostic accuracy.

\section{Limitations}

One limitation of the study was that the patients were discharged in less than 24 hours, so the final evaluation and collection of the last BNP was not possible.

\section{- CONCLUSION}

We conclude that, in patients hospitalized for ADHF, the behavior of BNP in peripheral blood paralleled the DCs of Excess fluid volume that indicate clinical congestion; as clinical compensation was achieved, both the frequency and number of DCs and the concentration of BNP decreased.

\section{Clinical Implications}

Our findings demonstrate the importance of adding BNP levels to the NANDA-I classification as a DC of the diagnosis
Excess fluid volume. Use of this biomarker can add accuracy to the clinical assessment of patients suspected of having this diagnosis. Accurate diagnosis, in turn, facilitates the achievement of favorable patient outcomes.

This study demonstrated the feasibility of BNP as another parameter that can be added to practice in order to improve the diagnostic accuracy in patients with HF. The teaching of clinical evaluation should value other parameters that may improve nurses' ability to diagnose. Studies in practice scenarios approximate the translation of knowledge immediately at the end of the research.

\section{QREFERENCES}

1. Rohde LEP, Montera MW, Bocchi EA, Clausell NO,Albuquerque DC. Diretriz Brasileira de Insuficiência Cardíaca Crônica e Aguda. Arq Bras Cardiol. 2018;111(3):436-539 . doi: https://doi.org/10.5935/abc.20180190

2. Savarese G, Lund LH. Global public health burden of heart failure. Card Fail Rev. 2017;3(1):7-11. doi: https://doi.org/10.15420/cfr.2016:25:2

3. Ponikowski P, Voors AA, Anker SD, Bueno H, Cleland JGF, Coats AJS, Falk V, et al. 2016 ESC Guidelines for the diagnosis and treatment of acute and chronic heart failure: the Task Force for the diagnosis and treatment of acute and chronic heart failure of the European Society of Cardiology (ESC) developed with the special contribution of the Heart Failure Association (HFA) of the ESC. Eur Heart J. 2016;37(27):2129-200. doi: https://doi.org/10.1093/eurheartj/ehw128

4. Natella PA, Le Corvoisier P, Paillaud E, Renaud B, Mahé I, Bergmann JF, et al. Long-term mortality in older patients discharged after acute decompensated heart failure: a prospective cohort study. BMC Geriatrics. 2017;17:34. doi: https://doi.org/10.1186/s12877-017-0419-2

5. Martins QCS, Aliti GB, Linhares JC, Rabelo ER. Excess fluid volume: clinical validation in patients with decompensated heart failure. Rev Latino-Am Enfermagem. 2011;19(3):1-8. doi: https://doi.org/10.1590/S0104-1169201 1000300013

6. Collins S, Storrow AB, Albert NM, Butler J, Ezekowitz J, Felker GM. Early management of patients with acute heart failure: state of the art and future directions: a consensus document from the Society for Academic Emergency Medicine/Heart Failure Society of America Acute Heart Failure Working Group. J Card Fail. 2015;21(1):27-43. doi: https://doi.org/10.1016/j. cardfail.2014.07.003

7. Aliti GB, Linhares JC, Linch GF, Ruschel KB, Rabelo ER. [Signs and symptoms in patients with decompensated heart failure: inference of priority nursing diagnoses]. Rev Gaúcha Enferm. 2011;32(3):590-5. Portuguese. doi: https:// doi.org/10.1590/S1983-14472011000300022

8. Sauer J, Rabelo ER, Castro RA, Goldraich L, Rohde LE, Clausell N, et al. Nurses' performance in classifying heart failure patients based on physical exam: comparison with cardiologist's physical exam and levels of N-terminal pro-Btype natriuretic peptide. J Clin Nurs. 2010;19(23-24):3381-9. doi: https://doi. org/10.1111/j.1365-2702.2010.03403.x

9. Martindale JL, Wakai A, Collins SP, Levy PD, Diercks D, Hiestand BC, et al. Diagnosing acute heart failure in the emergency department: a systematic review and meta-analysis. Acad Emerg Med. 2016;23(3):223-42. doi: https:// doi.org/10.1111/acem. 12878 
10. Chen $\mathrm{LJ}$, Hung $\mathrm{CL}$, Yeh HI, Jeng MJ, Su CH, Wu TY, et al. The utilization and prognostic impact of B-type Natriuretic Peptide in hospitalized acute decompensated heart failure in an Asian population. Cardiovasc Disord. 2016;16:178. doi: https://doi.org/10.1186/s12872-016-0342-z

11. Herdman TH, Kamitsuru S, editors. NANDA International nursing diagnoses: definitions \& classification, 2015-2017. 10 $0^{\text {th }}$ ed. Oxford: Wiley-Blackwell; 2014.

12. Francis $G$, Felker $G$, Tang W. A test in context critical evaluation of natriuretic peptide testing in heart failure. J Am Coll Cardiol. 2016;67(3):330-7. doi: https://doi.org/10.1016/j.jacc.2015.10.073

13. Roberts E, Ludman AJ, Dworzynski K, Al-Mohammad A, Cowie MR, McMurray $J J V$, et al. The diagnostic accuracy of the natriuretic peptides in heart failure: systematic review and diagnostic meta-analysis in the acute care setting. BMJ. 2015;350:h910. doi: https://doi.org/10.1136/bmj.h910

14. Carlson KJ, Lee DCS, Goroll AH, Leahy M, Johnson RA. An analysis of physicians' reasons for prescribing long-term digitalis therapy in outpatients. J Chron Dis. 1985;38(9):733-9. doi: https://doi.org/10.1016/0021-9681 (85) $90115-8$

15. Yanci CW, Jessup M, Bozkurt B, Butler J, Casey Jr DE, Colvin MM, et al. 2017 ACC/AHA/HFSA focused update of the 2013 ACCF/AHA Guideline for the Management of Heart Failure: a report of the American College of Cardiology/ American Heart Association Task Force on Clinical Practice Guidelines and the Heart Failure Society of America. Circulation. 2017;136(6):e137-61. doi: https://doi.org/10.1161/CIR.0000000000000509
16. Fukuda $H$, Suwa $H$, Nakano A, Sakamoto M, Imazu M, Hasegawa T, et al. Non-linear equation using plasma brain natriuretic peptide levels to predict cardiovascular outcomes in patients with heart failure. Sci Rep. 2016;6:37073. doi: https://doi.org/10.1038/srep37073

17. Omar HR, Guglin M. A single BNP measurement in acute heart failure does not reflect the degree of congestion. J Crit Care. 2016;33:262-5. doi: https://doi. org/10.1016/j.jcrc.2016.02.023

18. De Vecchis R, Ariano C, Giandomenico G, Di Maio M, Baldi C. Change of serum BNP between admission and discharge after acute decompensated heart failure is a better predictor of 6-month all-cause mortality than the single BNP value determined at admission. J Clin Med Res. 2016;8(10):737-42. doi: https://doi. org/10.14740/jocmr2691w

19. Feola M, Testa M, Leto L, Cardone M, Sola M, Rosso GL. Role of galectin-3 and plasma B type-natriuretic peptide in predicting prognosis in discharged chronic heart failure patients. Medicine (Baltimore). 2016;95(26):401-4. doi: https:// doi.org/10.1097/MD.0000000000004014

\section{Acknowledgment:}

Research and Events Incentive Fund of the Hospital de Clínicas de Porto Alegre (FIPE-HCPA)

\section{- Corresponding author:}

Eneida Rejane Rabelo da Silva

E-mail: eneidarabelo@gmail.com

\section{Editor-in-chief:}

Maria da Graça Oliveira Crossetti 


\section{Erratum of article:}

Trojahn MM, Barilli SLS, Bernardes DS, Pedraza LL, Aliti GB, Rabelo-Silva ER. B-type natriuretic peptide levels and diagnostic accuracy: excess fluid volume. Rev Gaúcha Enferm. 2020;41 (esp):e20190095. doi: https://doi.org/10.1590/1983-1447.2020.20190095

\section{On page 1, Authors:}

where it reads:

Daniela dos Santos Bernardes

\section{should read:}

Daniela de Souza Bernardes 